\title{
Key Ratios Analysis between Conventional and Islamic Banking in Bangladesh
}

\author{
Ayesha Siddiqua $^{1}$, A. N. M. Minhajul Haque Chowdhury ${ }^{2 *}$, Md. Jahangir Alam \\ Siddikee $^{3}$, Abu Sayed Md. Mahmudul Haque Chowdhury ${ }^{4}$, Shahnaz Parvin ${ }^{5}$
}

\author{
1,2MBA Student, Department of Finance and Banking, Hajee Mohammad Danesh Science and Technology \\ University, Dinajpur-5200, BANGLADESH \\ ${ }^{3,5}$ Assistant Professor, Department of Finance and Banking, Hajee Mohammad Danesh Science and Technology \\ University, Dinajpur-5200, BANGLADESH \\ ${ }^{4}$ Senior Lecturer, Department of English, University of Development Alternative, Dhaka-1209, BANGLADESH \\ *Corresponding Contact: \\ Email: mhchowdhury2016@gmail.com
}

\begin{abstract}
The proliferation of banking sector is an indicator of economic growth in Bangladesh. Conventional Banks as well as the Islamic Banks significantly influence the national economy although there are a number of dissimilarities between the two banking systems. This study was carried out to identify the differences of Conventional and Islamic Banking sectors in terms of ratio analysis. A total of 10 banks in which 5 Conventional and 5 Islamic banks were selected for the study. Some key financial ratios were being used for the analysis. It is found from the study that the Conventional and Islamic Banks had much influence on the national economy as they hold the deposit of general public and invest the funds in profitable projects. The earnings per share (EPS), return on asset (ROA), return on equity (ROE) and return on capital employed (ROCE) were greater in Islamic Banks. It clearly indicates that the Islamic Banks were more profitable and performing a good job in the context of Bangladesh although people preferred Conventional Banking most.
\end{abstract}

Key Words: Bank, Conventional banking, Islamic banking, ratio analysis

JEL Classification Code: G 21

\section{INTRODUCTION}

Economic development of a country and the contribution of banks are positively related. Among several factors, a country's economic growth is mostly depending on the financial sector performance especially the banking sector. Nowadays we cannot think of a country's economic system without banks. Banks are consistently serving the economy for the welfare of the society as well as their own. Conventional banks and Islamic banks are different in some aspects, but their operations have a great significance in the economic growth of any country. 


\section{Objective of the Study}

The objectives of the study are to analyze the key ratios and to compare those ratios between Conventional and Islamic Banking systems in Bangladesh.

\section{LITERATURE REVIEW}

Onakoya and Onakoya (2013) observed that Conventional Banking system utilizes a pooling of debt and equity in project financing and a fixed percentage of interest is expected from the debt finance. On the other hand Islamic Banking system based on the tenets of Islamic Shariah requires equity participation in investment. According to Siraj and Pillai (2012) Islamic banking is based on Islami Shariah and its services are interest free founded on profit-loss and risk sharing while Conventional banks offer its services those are interest based. This study is based on ratio analysis which involves determining the relationship between two variables expressed mathematically. Gitman (2009) described Ratio analysis as a method of calculating and interpreting financial ratios to analyze and monitor the firm's performance. The basic inputs to ratio analysis are the firms' income statement and balance sheet. Essien and Enifiok (2006) observed that financial statements carry a lot of information that are hidden in the figures. The figures in the financial statements become more useful when they are related to each other or to some other relevant data. The users of financial information establish relationship among selected data through ratio analysis. Innocent et al. (2013) argued that financial ratio analysis is a vital one as the profitability of an enterprise is affected by such decision. One of the key elements of a firm's financial strategy is the successful selection and use of appropriate financial ratios. Pandey (2010) describes that ratio analysis is a powerful tool of financial analysis. A ratio is used as a benchmark for evaluating the financial position and performance of a firm. For this the relationship between two accounting figures, expressed mathematically, is well known as financial ratio. Innocent (2015) observed that financial ratio analysis relationship has been discovered as having immense potential to improve an organization's revenue generation ability and at the same time minimize the cost. Muhammad et al. (2013) said that the result of financial ratio is obtained by dividing a financial data with other and is applied to indicate the relationship of different financial variable. They added that the most common formation sources are balance sheet and income statement of a firm. Shah (2015) described financial ratio as a relationship between tow accounting figures, expressed mathematically. He added that ratio analysis helps to ascertain the financial condition of the firm. Kumbirai and Webb (2010) observed that financial ratios are devoted to measure the performance of Commercial Banks and the ratios are also used to recognize unique bank strengths and weaknesses which provides the information of bank profitability, liquidity and credit quality. Chandra (2008) said that a study of ratios between various items or group of items in financial statement is known as financial ratio analysis. Mughal et al. (2015) compared Conventional and Islamic Banks on the basis of ROA, ROE and EPS and the result reveals that Conventional Banks are more Profitable than Islamic Banks in Pakistan in terms of ROA, ROE, and EPS. Haque (2013) evaluated the performances of some commercial banks based on some key financial ratios for the period of 2006-2011. She calculated return on assets, cash ratio, loan to deposit ratio, equity to total assets ratio, net asset turnover, fixed asset turnover and net profit margin. 


\section{Research Methodology and Design}

To conduct this study researcher used data from secondary sources. There were 5 Islamic Banks and 5 Conventional banks which were selected for the study. The names of selected banks are narrated below:

\begin{tabular}{|c|l|c|c|l|c|}
\hline No. & Conventional Banks & Contraction & No. & Islamic Banks & Contraction \\
\hline 1. & IFIC Bank Limited & IFIC & 1. & Al-Arafah Islami Bank Limited & AIBL \\
\hline 2. & Mutual Trust Bank Limited & MTBL & 2. & EXIM Bank Limited & EXIM \\
\hline 3. & NCC Bank Limited & NCC & 3. & Islami Bank Bangladesh Limited & IBBL \\
\hline 4. & Sonali Bank Limited & SBL & 4. & Shahjalal Islami Bank Limited & SJIBL \\
\hline 5. & Southeast Bank Limited & SEBL & 5. & Social Islami Bank Limited & SIBL \\
\hline
\end{tabular}

The secondary data came from various published materials in journals and reports, Banks' annual report (2011-2014), websites. The researcher compared some key ratios of both Islamic and Conventional Banks.

The financial ratios those had been used in this study are given below:

i. Earnings per Share (EPS) $=\frac{\text { Earnings avialable to common shareholders }}{\text { No.of common share outstanding }}$

ii. Net Asset Value per Share (NAVPS) $=\frac{\text { Net Asset }}{\text { Issued Common Share }}$

iii. Return on Equity $(\mathrm{ROE})=\frac{\text { Earnings avialable to common shareholders }}{\text { Average Shareholder Equity }}$

iv. Return on Asset $(\mathrm{ROA})=\frac{\text { Earnings avialable to common shareholders }}{\text { Average } \text { Total Asset }}$

v. Capital Adequacy Ratio $(\mathrm{CAR})=\frac{\text { Tier I Capital+Tier II Capital }}{\text { Risk weighted assets }}$

vi. Debt Ratio $(\mathrm{DR})=\frac{\text { Total Liabilities }}{\text { Total Asset }}$

vii. Fixed asset to Net Worth Ratio $($ FANWR $)=\frac{\text { Fixed Asset }}{\text { Netr Worth }}$

viii. Solvency Ratio $(\mathrm{SR})=\frac{\text { Profit After tax }+ \text { Depreciation }}{\text { Total Liabilities }}$

ix. Cost/ Income Ratio in Operating Business $(\mathrm{CIR})=\frac{\text { Total Operating Cost }}{\text { Total Operating Income }}$

x. Return on Capital Employed $($ ROCE $)=\frac{\text { Profit After Tax }}{\text { Total Asset-Current Liabilities }}$

xi. Cash Flow to Debt Ratio $($ CFDR $)=\frac{\text { Net Cash Flow received from Operating Activities }}{\text { Totral liabilities }}$

xii. Total Equity to Total Asset Ratio $($ TETAR $)=\frac{\text { Total Equity }}{\text { Total Asset }}$ 


\section{RESULTS AND ANALYSIS}

The financial ratios of Conventional and Islamic banks during 2011-2014 are presented in Table 1 and 2 respectively.

Table 1: Summary of key ratios of Conventional Banks

\begin{tabular}{|c|c|c|c|c|c|c|c|c|c|c|c|c|c|}
\hline \multirow{2}{*}{ Year } & EPS & NAVPS & ROE & ROA & CAR & DR & FANWR & SR & CIR & ROCE & CFDR & TETAR \\
\cline { 2 - 12 } & $($ Tk.) & $($ Tk.) & $(\%)$ & $(\%)$ & $(\%)$ & $(\%)$ & $(\%)$ & $(\%)$ & $(\%)$ & $(\%)$ & $(\%)$ & $(\%)$ \\
\hline \multicolumn{10}{|c|}{ IFIC Bank Limited } \\
\hline 2011 & 2.40 & 52.71 & 13.36 & 1.03 & 10.13 & 92.72 & 33.13 & 1.24 & 50.35 & 4.80 & 5.70 & 7.28 \\
\hline 2012 & 1.20 & 20.17 & 2.15 & 0.01 & 10.21 & 93.92 & 33.92 & 0.64 & 56.72 & 1.93 & 9.31 & 6.08 \\
\hline 2013 & 3.72 & 25.87 & 19.37 & 1.31 & 10.32 & 92.65 & 24.41 & 1.56 & 54.93 & 8.34 & 7.01 & 7.35 \\
\hline 2014 & 4.71 & 27.18 & 18.96 & 1.41 & 10.40 & 92.52 & 24.77 & 1.67 & 58.49 & 8.86 & 3.38 & 7.48 \\
\hline \multicolumn{10}{|c|}{ Mutual Trust Bank Limited } \\
\hline 2011 & 1.59 & 18.93 & 8.79 & 0.60 & 11.96 & 93.69 & 32.25 & 0.80 & 61.17 & 3.52 & 3.99 & 6.31 \\
\hline 2012 & 1.29 & 19.01 & 6.80 & 0.39 & 10.71 & 94.81 & 49.34 & 0.62 & 62.01 & 2.72 & 4.37 & 5.19 \\
\hline 2013 & 1.86 & 17.71 & 11.15 & 0.59 & 11.57 & 94.61 & 45.11 & 0.88 & 56.14 & 4.05 & 4.52 & 5.39 \\
\hline 2014 & 3.12 & 22.00 & 15.74 & 0.88 & 10.77 & 94.18 & 36.76 & 1.16 & 54.53 & 5.65 & 1.28 & 5.82 \\
\hline \multicolumn{10}{|c|}{ NCC Bank Limited } \\
\hline 2011 & 3.33 & 19.12 & 22.82 & 2.52 & 11.26 & 89.09 & 13.45 & 2.83 & 29.03 & 13.41 & 1.13 & 10.91 \\
\hline 2012 & 2.09 & 17.47 & 12.28 & 1.25 & 11.47 & 90.37 & 14.59 & 1.48 & 35.35 & 7.24 & 3.36 & 9.63 \\
\hline 2013 & 1.42 & 17.37 & 10.61 & 1.08 & 11.87 & 89.34 & 13.24 & 1.52 & 38.46 & 5.65 & 2.78 & 10.66 \\
\hline 2014 & 1.86 & 17.88 & 11.17 & 1.18 & 13.47 & 89.44 & 18.05 & 1.59 & 43.29 & 3.39 & 1.45 & 10.56 \\
\hline \multicolumn{10}{|c|}{ Sonali Bank Limited } \\
\hline 2011 & 108.65 & 498.87 & 21.34 & 1.52 & 12.60 & 91.93 & 41.09 & 1.63 & 81.93 & 6.22 & 3.96 & 8.07 \\
\hline 2012 & -28.48 & 199.11 & -80.37 & -4.30 & -0.94 & 97.03 & 103.37 & -4.24 & 51.09 & -21.70 & -3.99 & 2.97 \\
\hline 2013 & 30.64 & 443.43 & 9.54 & 0.43 & 7.59 & 94.15 & 65.21 & 0.49 & 80.08 & 2.07 & 16.36 & 5.85 \\
\hline 2014 & 31.72 & 190.32 & 10.07 & 0.67 & 12.24 & 93.65 & 55.22 & 0.75 & 60.36 & 3.82 & 8.71 & 6.35 \\
\hline \multicolumn{10}{|c|}{ Southeast Bank Limited } \\
\hline 2011 & 2.19 & 23.29 & 10.47 & 1.32 & 11.46 & 87.74 & 38.04 & 1.57 & 34.22 & 6.90 & 8.63 & 12.26 \\
\hline 2012 & 1.89 & 22.65 & 8.42 & 0.95 & 10.87 & 89.58 & 38.79 & 1.18 & 42.52 & 5.46 & 7.62 & 10.42 \\
\hline 2013 & 3.68 & 25.11 & 16.20 & 1.64 & 10.90 & 90.07 & 35.53 & 1.85 & 54.54 & 9.52 & 10.35 & 9.93 \\
\hline 2014 & 4.18 & 26.77 & 16.51 & 1.67 & 21.41 & 89.62 & 32.23 & 1.98 & 40.14 & 9.76 & 2.63 & 10.38 \\
\hline
\end{tabular}

Table 1 show that IFIC Bank Limited had highest NAVPS in 2011 and the highest DR, FANWR, and CFDR in 2012. This bank experienced the highest ROE in 2013 while the highest EPS, ROA, CAR, SR, CIR, and ROCE were in 2014. The CAR and TETAR of Mutual Trust Bank Limited were the highest in 2011 and DR, FANWR, and CIR were the highest in 2012 while in 2014 this bank had the highest EPS, NAVPS, ROE, ROA, SR, and ROCE. NCC Bank Limited had the highest EPS, NAVPS, ROE, ROA, SR, ROCE, and TETAR in 2011 and the highest DR and CFDR in 2012. In 2014 this bank had the maximum CAR, FANWR, and CIR. In 2011 Sonali Bank Limited had the highest EPS, NAVPS, ROE, ROA, CAR, SR, CIR, ROCE, and TETAR while in 2012 it had the highest DR and FANWR. Southeast Bank Limited experienced the maximum DR, CIR and CFDR in 2013 while it had the maximum EPS, NAVPS, ROE, ROA, CAR, SR, and ROCE in 2014. 
Table 2: Summary of key ratios of Islamic Banks

\begin{tabular}{|c|c|c|c|c|c|c|c|c|c|c|c|c|c|}
\hline \multirow{2}{*}{ Year } & EPS & NAVPS & ROE & ROA & CAR & DR & FANWR & SR & CIR & ROCE & CFDR & TETAR \\
\cline { 2 - 13 } & $($ Tk.) & (Tk.) & $(\%)$ & $(\%)$ & $(\%)$ & $(\%)$ & $(\%)$ & $(\%)$ & $(\%)$ & $(\%)$ & $(\%)$ & $(\%)$ \\
\hline \multicolumn{10}{|c|}{ Al-Arafah Islami Bank Limited } \\
\hline 2011 & 2.79 & 20.34 & 20.19 & 2.43 & 13.47 & 88.77 & 8.08 & 2.43 & 26.25 & 11.58 & 5.19 & 9.21 \\
\hline 2012 & 2.38 & 19.70 & 14.94 & 1.52 & 11.75 & 90.59 & 17.04 & 1.57 & 31.89 & 7.97 & 6.48 & 8.34 \\
\hline 2013 & 2.16 & 19.29 & 15.11 & 1.41 & 14.66 & 109.72 & 15.64 & 1.59 & 35.02 & 7.91 & 5.67 & 10.13 \\
\hline 2014 & 2.20 & 19.18 & 13.58 & 1.21 & 14.03 & 91.37 & 1.47 & 1.34 & 33.99 & 6.70 & 2.30 & 7.88 \\
\hline \multicolumn{10}{|c|}{ EXIM Bank Limited } \\
\hline 2011 & 1.92 & 15.69 & 14.99 & 1.66 & 10.88 & 88.85 & 3.26 & 1.88 & 8.28 & 10.76 & 7.68 & 11.16 \\
\hline 2012 & 1.98 & 15.74 & 13.43 & 1.40 & 10.94 & 90.09 & 2.66 & 1.49 & 20.70 & 9.19 & 10.32 & 9.91 \\
\hline 2013 & 1.47 & 17.72 & 10.18 & 1.04 & 13.30 & 89.52 & 15.56 & 1.18 & 40.22 & 6.59 & 0.13 & 10.48 \\
\hline 2014 & 1.92 & 17.90 & 11.34 & 1.15 & 11.70 & 90.13 & 14.41 & 1.28 & 40.52 & 1.44 & 1.48 & 10.21 \\
\hline \multicolumn{10}{|c|}{ Islami Bank Bangladesh Limited } \\
\hline 2011 & 3.70 & 27.60 & 18.10 & 1.29 & 13.13 & 92.91 & 25.75 & 1.39 & 36.24 & 9.73 & 4.13 & 7.09 \\
\hline 2012 & 4.49 & 31.70 & 16.70 & 1.29 & 13.53 & 91.78 & 37.36 & 1.38 & 36.03 & 8.67 & 4.64 & 8.22 \\
\hline 2013 & 3.12 & 29.90 & 12.06 & 0.98 & 14.26 & 91.99 & 35.96 & 1.15 & 43.70 & 6.78 & 6.73 & 8.00 \\
\hline 2014 & 2.46 & 28.93 & 8.78 & 0.66 & 12.83 & 92.85 & 34.20 & 0.80 & 44.06 & 4.71 & 8.35 & 7.15 \\
\hline \multicolumn{10}{|c|}{ Shahjalal Islami Bank Limited } \\
\hline 2011 & 2.10 & 18.28 & 17.59 & 1.38 & 11.40 & 92.45 & 19.26 & 1.41 & 34.65 & 9.28 & 1.52 & 7.35 \\
\hline 2012 & 3.13 & 17.77 & 19.87 & 1.45 & 12.31 & 92.62 & 29.76 & 1.51 & 29.55 & 10.37 & 4.09 & 7.22 \\
\hline 2013 & 1.78 & 16.76 & 12.66 & 0.98 & 13.69 & 91.45 & 26.80 & 1.21 & 46.57 & 5.17 & 5.65 & 8.37 \\
\hline 2014 & 1.02 & 16.26 & 6.60 & 0.57 & 13.61 & 90.78 & 26.86 & 0.76 & 52.93 & 2.77 & 3.95 & 9.04 \\
\hline \multicolumn{10}{|c|}{ Social Islami Bank Limited } \\
\hline 2011 & 1.72 & 14.64 & 15.23 & 1.50 & 13.17 & 88.85 & 22.82 & 1.49 & 34.45 & 7.48 & 1.63 & 11.15 \\
\hline 2012 & 2.29 & 15.88 & 15.02 & 1.48 & 11.52 & 91.16 & 22.23 & 1.54 & 34.36 & 8.70 & 6.29 & 8.84 \\
\hline 2013 & 1.78 & 15.77 & 11.79 & 1.04 & 11.64 & 91.23 & 24.02 & 1.24 & 47.23 & 6.31 & -1.56 & 8.77 \\
\hline 2014 & 2.74 & 17.31 & 16.58 & 1.38 & 11.36 & 92.07 & 22.05 & 1.51 & 40.82 & 8.32 & 2.17 & 7.93 \\
\hline
\end{tabular}

From Table 2 it is clear that Al-Arafah Islami Bank Limited had the highest EPS, NAVPS, ROE, ROA, SR and ROCE in 2011 and the highest FANWR and CFDR in 2012. In 2013 it experienced the maximum CAR, DR, CIR and TETAR. In 2011 EXIM Bank Limited had the highest ROE, ROA, SR, ROCE, and TETAR while EPS and CFDR were the highest in 2012. In 2013 CAR and FANWR were the highest and NAVPS, DR, and CIR were the highest in 2014. Islami Bank Bangladesh Limited had the highest ROE, DR, and CIR in 2011 while it had the highest EPS, ROA, FANWR, and TETAR in 2012. This bank experienced the highest CAR and CFDR in 2013 and CIR in 2014. It is observed that in 2012 Shahjalal Islami Bank Limited had the highest EPS, ROE, ROA, DR, FANWR, SR, and ROCE while the highest CAR and CFDR was in 2013 and the highest CIR and TETAR were in 2014. In the case of Social Islami Bank Limited the ROA, CAR, and TETAR were the maximum in 2011 and SR, ROCE, and CFDR were the maximum in 2012. In 2013 this bank had the highest FANWR and CIR while EPS, NAVPS, ROE, and DR were the highest in 2014.

Table 3 summarizes the average ratios of Conventional and Islamic Banks for 2011 to 2014. The average Earnings per Share (EPS) of all the selected Conventional Banks during that period was negative whereas the average EPS of Islamic Banks was Tk. 2.41. Average NAVPS of Conventional Banks was better than the Islamic Banks. Average ROE, ROA, CAR, SR, and ROCE were greater in Islamic Banks. Debt Ratio and Cost Income ratios were higher in Conventional Banks. This table indicates that Islamic Banks were in better position than the Conventional Banks. 
Table 3: Comparison of ratios of Conventional and Islamic Banks

\begin{tabular}{|c|l|c|c|c|}
\hline No. & \multicolumn{1}{|c|}{ Ratios } & Conventional Banks & Islamic Banks & Difference \\
\hline 1 & Earnings per Share & -3.44 & 2.41 & -5.85 \\
\hline 2 & Net Asset Value per Share & 85.25 & 19.82 & 65.43 \\
\hline 3 & Return on Equity & 8.27 & 14.24 & -5.97 \\
\hline 4 & Return on Asset & 0.86 & 1.29 & -0.43 \\
\hline 5 & Capital Adequacy Ratio & 11.01 & 12.66 & -1.65 \\
\hline 6 & Debt Ratio & 92.06 & 91.96 & 0.10 \\
\hline 7 & Fixed asset to Net Worth Ratio & 37.43 & 20.26 & 17.17 \\
\hline 8 & Solvency Ratio & 1.06 & 1.41 & -0.35 \\
\hline 9 & Cost/ Income Ratio & 52.27 & 35.88 & 16.39 \\
\hline 10 & Return on Capital Employed & 4.18 & 7.52 & -3.34 \\
\hline 11 & Cash Flow to Debt Ratio & 5.13 & 4.34 & 0.79 \\
\hline 12 & Total Equity to Total Asset Ratio & 7.95 & 8.82 & -0.87 \\
\hline
\end{tabular}

\section{CONCLUSION}

Banks have a direct economic effect to a country. Conventional and Islamic Banks both were compared in the study. In present days as a Muslim country, the saving group of Bangladesh showing interest in Islamic banking. Conventional Banks are running a business as well. This study disclosed some results which illustrate that Islamic Banking is dominating the Conventional Banking. The differences of EPS, ROA, and ROE between the Conventional and Islamic Banks indicated that Islamic Banks were more profitable in the context of Bangladesh. The Total Asset to Total Equity Ratio of Islamic Banks was higher which indicates that Islamic Banks are better in risk management. The study follows that the Islamic Banking has a great prospect in the economy of Bangladesh.

\section{ACKNOWLEDGEMENT}

The Authors wish to thank Professor Md. Ruhul Amin, Vice Chancellor of Hajee Mohammad Danesh Science and Technology University, Bangladesh for developing a better environment and infrastructure in the University to motivate the teachers and students towards research related works.

\section{REFERENCES}

Chandra, P. (2008), Investment Analysis and Portfolio Management (3rd Ed.), New Delhi: Tata McGrawHill Publishing Company Ltd.

Chowdhury, A., Siddiqua, A., \& Chowdhury, A. (2016). Relationship between Liquidity Risk and Net Interest Margin of Conventional Banks in Bangladesh. Asian Business Review, 6(3), 175-178.

Essien, E. E. (2006), Entrepreneurship Concept and Practice, uyo: Abaem Publishing Co.

Fatema, N., \& Ibrahim, A. (2013). Comparative study of Profitability and Liquidity analysis of Islamic Banks in Bangladesh. Global Disclosure of Economics and Business, 2(1), 29-46. Retrieved from http: / /i-proclaim.my/archive/index.php/gdeb/article/view/135

Ferdous, M., \& Moniruzzaman, M. (2015). An Empirical Evidence of Corporate Social Responsibility by Banking Sector based on Bangladesh. Asian Business Review, 3(4), 82-87. doi: http:/ /dx.doi.org/10.18034/abr.v3i4.283

Gitman, L. J. (2009), Principles of Managerial Finance (12th Ed.), Pearson Education Inc. pp. 42-103.

Haque, S. (2013), "The performance of private commercial banks: a case study of Bangladesh", IOSR Journal of Business and Management, Vol. 12, No. 1, pp.19-25.

Innocent, E. C. (2015), “The relationship between financial ratio analysis and corporate profitability: a study of selected quoted oil and gas companies in Nigeria", European Journal of Accounting, Auditing and Financial Research, Vol. 3, No. 2, pp. 17-34. 
Innocent, E. C., Mary, O. I. and Matthew, O. M. (2013), "Financial ratio analysis as a determinant of profitability in Nigerian pharmaceutical industry", International Journal of Business and Management, Vol. 8, No. 8, pp. 107-117.

Kumbirai, M. and Webb, R. (2010), "A financial ratio analysis of Commercial Bank performance in South Africa", African Review of Economics and Finance, Vol. 2, No. 1, pp. 30-53.

Mughal, M. K., Waleed, A. and Shah, M. B. (2015), “Comparison of Islamic and Conventional Banks' performance", International Journal of Research in Economics and Social Sciences, Vol. 5, No. 6, pp. 37-46.

Muhammad, H., Shah, B., Islam, Z., Waqas, M. and Khan, D. (2013), "Comparative evaluation of performance of Pakistan Tobacco Company (PTC) and Philip Morris Pakistan Limited (PMPKL) through ratio analysis", International Journal of Management Science and Business Research, Vol. 3, No. 1, pp. 146-156.

Onakoya, A. B. and Onakoya, A. O. (2013), "The performance of Conventional and Islamic banks in the United Kingdom: A comparative analysis", Journal of Research in Economics and International Finance, Vol.2, No. 2, pp. 29-38.

Pandey, I. M. (2010). Financial Management. (10th ed.), New Delhi: Vikas Publishing House PVT Ltd.

Rahman, M., Ahsan, M., Hossain, M., \& Hoq, M. (2015). Green Banking Prospects in Bangladesh. Asian Business Review, 2(2), 59-63. doi:http:/ /dx.doi.org/10.18034/abr.v2i2.305

Shah, M. B. (2015), "A financial ratio analysis of Hindustan Unilever Limited (HUL)", RESEARCH HUB- International Multidisciplinary Research Journal (RHIMRJ), Vol. 2, No. 5, pp. 1-5.

Siraj, K. K. and Pillai, P. S. (2012), "Comparative study on performance of Islamic banks and Conventional banks in GCC region", Journal of Applied Finance \& Banking, Vol. 2, No. 3, pp. 123-161.

\section{APPENDICES}

Appendix 1. Summary of Financial data of Conventional Banks (Figures in Millions)

\begin{tabular}{|c|c|c|c|c|c|c|c|c|c|c|c|c|c|}
\hline & Year & 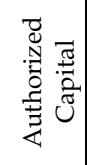 & 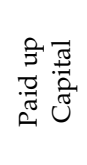 & 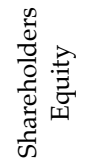 & 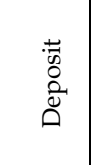 & 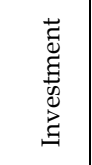 & 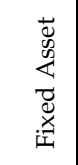 & 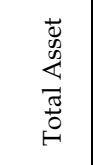 & 㞼 & 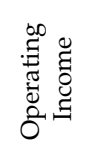 & 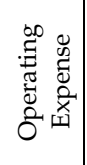 & 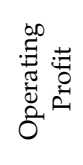 & 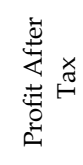 \\
\hline & & (Tk.) & (Tk.) & (Tk.) & (Tk.) & (Tk.) & (Tk.) & (Tk.) & (Tk.) & (Tk.) & (Tk.) & (Tk.) & (Tk.) \\
\hline \multirow{4}{*}{ IFIC } & 2011 & 20000 & 2768 & 6686 & 73042 & 12372 & 2215 & 91797 & 85111 & 5796 & 2918 & 2878 & 832 \\
\hline & 2012 & 20000 & 3460 & 6980 & 92291 & 15836 & 2368 & 114773 & 107793 & 6535 & 3706 & 2828 & 417 \\
\hline & 2013 & 20000 & 3807 & 9849 & 110676 & 21898 & 2404 & 134052 & 124203 & 6624 & 3639 & 2985 & 1630 \\
\hline & 2014 & 20000 & 4378 & 11897 & 129863 & 24031 & 2947 & 159044 & 147147 & 7737 & 4526 & 3212 & 2061 \\
\hline \multirow{4}{*}{ MTBL } & 2011 & 10000 & 2544 & 4815 & 59051 & 19756 & 1553 & 76331 & 71516 & 3104 & 1899 & 1205 & 404 \\
\hline & 2012 & 10000 & 2544 & 4834 & 75140 & 23251 & 2385 & 93162 & 88328 & 3507 & 2175 & 1332 & 328 \\
\hline & 2013 & 10000 & 2798 & 5449 & 84373 & 25824 & 2458 & 101173 & 95723 & 4619 & 2593 & 2026 & 573 \\
\hline & 2014 & 10000 & 3078 & 6770 & 97106 & 20768 & 2489 & 116301 & 109530 & 5725 & 3122 & 2603 & 962 \\
\hline \multirow{4}{*}{$\mathrm{NCC}$} & 2011 & 10000 & 5942 & 11361 & 80902 & 20860 & 1528 & 104101 & 92740 & 6100 & 1771 & 4329 & 2364 \\
\hline & 2012 & 10000 & 6952 & 12144 & 96687 & 30875 & 1772 & 126068 & 113924 & 6349 & 2245 & 4105 & 1443 \\
\hline & 2013 & 10000 & 7647 & 13282 & 97987 & 19934 & 1759 & 124626 & 111344 & 6374 & 2451 & 3923 & 1349 \\
\hline & 2014 & 10000 & 8030 & 14357 & 105458 & 26598 & 2592 & 135997 & 121640 & 6626 & 2868 & 3758 & 1543 \\
\hline \multirow{4}{*}{ SBL } & 2011 & 20000 & 11250 & 56123 & 533123 & 132089 & 23060 & 695605 & 639481 & 23715 & 11237 & 12478 & 9982 \\
\hline & 2012 & 20000 & 11250 & 22400 & 599208 & 147018 & 23155 & 754616 & 732216 & 22620 & 11557 & 11064 & -3155 \\
\hline & 2013 & 20000 & 11250 & 49886 & 685755 & 270411 & 32530 & 852852 & 802966 & 15178 & 12154 & 3023 & 3447 \\
\hline & 2014 & 60000 & 31200 & 59380 & 777975 & 323023 & 32787 & 935286 & 875906 & 21724 & 13113 & 8611 & 5978 \\
\hline \multirow{4}{*}{ SEBL } & 2011 & 10000 & 8317 & 19384 & 127178 & 29847 & 7373 & 158079 & 138695 & 8168 & 2083 & 6086 & 1912 \\
\hline & 2012 & 10000 & 8733 & 19792 & 152901 & 37657 & 7678 & 189922 & 170130 & 7832 & 2336 & 5495 & 1649 \\
\hline & 2013 & 10000 & 8733 & 21940 & 177519 & 57589 & 7796 & 220931 & 198991 & 9685 & 2985 & 6700 & 3379 \\
\hline & 2014 & 15000 & 9170 & 24553 & 189473 & 56379 & 7912 & 236608 & 212055 & 11617 & 3327 & 8290 & 3837 \\
\hline
\end{tabular}

Source: Annual Report's data from 2011-2014 of IFIC Bank Ltd., Mutual Trust Bank Ltd., NCC Bank Ltd., Sonali Bank Ltd., Southeast Bank Ltd. 
Appendix 2. Summary of Financial data of Islamic Banks (Figures in Millions)

\begin{tabular}{|c|c|c|c|c|c|c|c|c|c|c|c|c|c|}
\hline & Year & 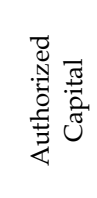 & 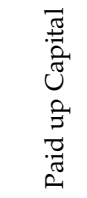 & 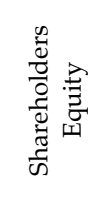 & $\begin{array}{l}+\vec{w} \\
0 \\
0 \\
0 \\
0\end{array}$ & 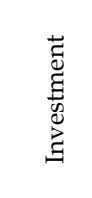 & 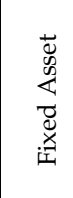 & 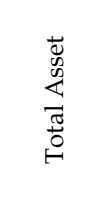 & 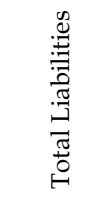 & 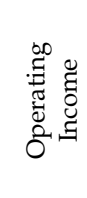 & 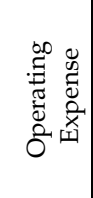 & 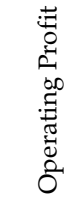 & 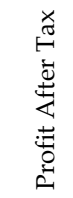 \\
\hline & & (Tk.) & (Tk.) & (Tk.) & (Tk.) & (Tk.) & (Tk.) & (Tk.) & (Tk.) & (Tk.) & (Tk.) & (Tk.) & (Tk.) \\
\hline \multirow{4}{*}{ AIBL } & 2011 & 10000 & 5893 & 9834 & 82187 & 81487 & 968 & 106768 & 94779 & 5866 & 1540 & 4327 & 2199 \\
\hline & 2012 & 10000 & 7131 & 12449 & 118683 & 112162 & 2395 & 149320 & 135270 & 6982 & 2227 & 4756 & 1945 \\
\hline & 2013 & 15000 & 8343 & 14499 & 140981 & 132854 & 2517 & 143162 & 157070 & 7616 & 2667 & 4949 & 2277 \\
\hline & 2014 & 15000 & 9470 & 16581 & 166851 & 155861 & 2661 & 210439 & 192279 & 9595 & 3262 & 6333 & 2325 \\
\hline \multirow{4}{*}{ EXIM } & 2011 & 20000 & 9224 & 14469 & 107515 & 107588 & 472 & 129710 & 115240 & 6615 & 2529 & 4086 & 2018 \\
\hline & 2012 & 20000 & 10515 & 16550 & 140025 & 129705 & 439 & 166998 & 150448 & 8117 & 2823 & 5294 & 2083 \\
\hline & 2013 & 20000 & 1156 & 20499 & 165392 & 156446 & 3190 & 195542 & 175043 & 9284 & 3331 & 4953 & 1886 \\
\hline & 2014 & 20000 & 12839 & 23768 & 200009 & 180723 & 3312 & 232834 & 209857 & 10315 & 4179 & 3136 & 2466 \\
\hline \multirow{4}{*}{ IBBL } & 2011 & 20000 & 10008 & 27614 & 341855 & 321643 & 7110 & 389376 & 361762 & 20123 & 7292 & 12832 & 4625 \\
\hline & 2012 & 20000 & 12510 & 39661 & 417846 & 398481 & 14817 & 482649 & 442988 & 24669 & 8889 & 15780 & 5617 \\
\hline & 2013 & 20000 & 14636 & 43764 & 472122 & 469094 & 15739 & 546369 & 502605 & 25322 & 11065 & 14257 & 5031 \\
\hline & 2014 & 20000 & 16100 & 46585 & 559714 & 560063 & 15930 & 651579 & 604995 & 27471 & 12103 & 15368 & 3967 \\
\hline \multirow{4}{*}{ SJIBL } & 2011 & 6000 & 4453 & 7917 & 82404 & 87046 & \begin{tabular}{|l|}
1568 \\
\end{tabular} & 107788 & 99646 & 4944 & 1713 & 3231 & 1290 \\
\hline & 2012 & 6000 & 5566 & 9661 & 101367 & 104899 & 2942 & 133900 & 124012 & 6569 & 1941 & 4628 & 1746 \\
\hline & 2013 & 10000 & 6679 & 10967 & 96141 & 97051 & 3000 & 130973 & 119779 & 5214 & 2428 & 2786 & 1306 \\
\hline & 2014 & 10000 & 7347 & 11715 & 98443 & 95303 & 3207 & 129532 & 117590 & 5216 & 2761 & 2455 & 748 \\
\hline \multirow{4}{*}{ SIBL } & 2011 & 10000 & 6394 & 9358 & 66462 & 57670 & 2135 & 83962 & 74603 & 4146 & 1428 & 2718 & 1032 \\
\hline & 2012 & 10000 & 6394 & 10153 & 93277 & 80689 & 2257 & 114829 & 104676 & 5549 & 1907 & 3643 & 1466 \\
\hline & 2013 & 10000 & 7031 & 11087 & 101842 & 92930 & 2663 & 126401 & 115314 & 5560 & 2626 & 2934 & 1252 \\
\hline & 2014 & 10000 & 7031 & 12173 & 124265 & 114144 & 2684 & 153585 & 141412 & 6798 & 2775 & 4023 & 1928 \\
\hline
\end{tabular}

Source: Annual Report's data from 2011-2014 of Al-Arafah Islami Bank Ltd., EXIM Bank Ltd., Islami Bank Bangladesh Ltd., Shahjalal Islami Bank Ltd., Social Islami Bank Ltd.

--0--

Publish Online and Print Version Both

ISSN Online: 2307-9592 